\title{
Prelimbic to Accumbens Core Pathway Is Recruited in a Dopamine-Dependent Manner to Drive Cued Reinstatement of Cocaine Seeking
}

\author{
-Ellen M. McGlinchey, ${ }^{1,2 *}$-Morgan H. James, ${ }^{2 *}$ Stephen V. Mahler, ${ }^{1,3}{ }^{-}$Caroline Pantazis, ${ }^{2}$ and Gary Aston-Jones ${ }^{2}$ \\ ${ }^{1}$ Department of Neurosciences, Medical University of South Carolina, Charleston, South Carolina 29403, ${ }^{2}$ Brain Health Institute, Rutgers University and \\ Rutgers Biomedical and Health Sciences, Piscataway, New Jersey 08854, and ${ }^{3}$ Department of Neurobiology and Behavior, University of California, Irvine, \\ California 92697
}

Glutamate inputs to nucleus accumbens (NAc) facilitate conditioned drug-seeking behavior and primarily originate from medial prefrontal cortex (mPFC), basolateral amygdala (BLA), and ventral subiculum of the hippocampus (vSub). These regions express Fos (a marker of neural activity) during cue-induced reinstatement of cocaine seeking, but only subpopulations of neurons within these regions drive drug seeking. One way to identify and functionally distinguish neural subpopulations activated during drug-seeking is to examine their projection targets. In rats, we examined Fos expression during cue-induced reinstatement of cocaine- and sucrose-seeking in prelimbic cortex (PL), infralimbic cortex (IL), BLA, and vSub neurons that project to NAc core (NAcC) or NAc shell (NAcSh). Neurons in PL, BLA, and vSub that project to NAcC, but not NAcSh, expressed Fos during cue-induced cocaine seeking, but not sucrose seeking. However, only activation of the PL-NAcC pathway positively correlated with cocaine reinstatement behavior, unlike BLA or vSub inputs to NAcC. To confirm a functional role for the PL-NAcC pathway, and to test the hypothesis that this pathway is recruited in a dopaminedependent manner, we used a pharmacological disconnection approach whereby dopamine signaling was blocked in PL and glutamate signaling was blocked in the contralateral NAcC. This disconnection attenuated cue-induced reinstatement of cocaine seeking but had no effect on reinstatement of sucrose seeking. Our results highlight a role for the PL-NAcC pathway in cocaine seeking and show that these glutamatergic projections are recruited in a dopamine-dependent manner to drive reinstatement.

Key words: basolateral amygdala; cocaine; dopamine; nucleus accumbens; prelimbic cortex; ventral subiculum

Significance Statement

Relapse represents a significant barrier to the successful treatment of cocaine addiction. Here, we characterize the relative activation of glutamatergic inputs to nucleus accumbens during cued reinstatement of cocaine seeking versus sucrose seeking. Prelimbic cortex (PL) projections to nucleus accumbens core (NAcC) uniquely expressed Fos in a manner that positively correlated with cocaine-seeking, but not sucrose-seeking, behavior. Additional functional experiments showed that the PL-NAcC pathway was recruited by drug-associated cues in a dopamine-dependent manner to drive cocaine-seeking, but not sucroseseeking, behavior. These data highlight PL neurons that project to NAcC, and their regulation by dopamine, as potential targets for therapeutics designed to treat cocaine relapse that do not affect natural reward seeking.

\section{Introduction}

Nucleus accumbens (NAc) is an integral structure in reward circuitry (Mogenson et al., 1980; Pennartz et al., 1994; Kalivas and
Volkow, 2005; Britt et al., 2012; Floresco, 2015). NAc receives multiple glutamatergic inputs, with major sources from medial prefrontal cortex (mPFC), basolateral amygdala (BLA), and

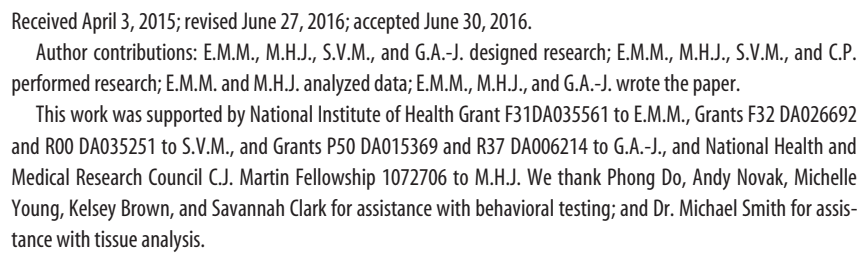

The authors declare no competing financial interests.

*E.M.M. and M.H.J. contributed equally to this study.

Correspondence should be addressed to Dr. Gary Aston-Jones, Brain Health Institute, Rutgers University and Rutgers Biomedical and Health Sciences, Room 259 SPH, 683 Hoes Lane West, Piscataway, NJ 08854. E-mail: aston.jones@rutgers.edu.

DOI:10.1523/JNEUROSCI.1291-15.2016

Copyright $\odot 2016$ the authors $\quad 0270-6474 / 16 / 368700-12 \$ 15.00 / 0$ 
ventral subiculum of the hippocampus (vSub). Studies show that these structures are involved in conditioned drug seeking (McFarland et al., 2003; McLaughlin and See, 2003; Sun and Rebec, 2003; Stefanik and Kalivas, 2013; Stefanik et al., 2013); however, recent evidence indicates that only subpopulations of neurons within brain structures drive drug-seeking behaviors (Bossert et al., 2011; Cruz et al., 2013, 2014; Moorman and AstonJones, 2015). The importance of these neural subpopulations for drug-seeking behavior may depend on their projection targets. For example, neurons in mPFC, BLA, and vSub activate during cue-induced cocaine seeking (as measured by $c$-fos mRNA or Fos protein) (Kufahl et al., 2009), but neurons in these regions that project to ventral tegmental area (VTA), a fundamental structure in addiction-related behavior, are not activated (Mahler and Aston-Jones, 2012). These findings indicate heterogeneous activity within these regions based on specific neural projection targets.

We examined the extent to which subpopulations of neurons in prelimbic cortex (PL), infralimbic cortex (IL), BLA, and vSub that project to NAc are activated by cues associated with cocaine or a natural reinforcer (sucrose), and tested the causal roles of activated circuits in reinstatement behavior. We distinguished NAc core (NAcC) and shell (NAcSh) as they show dissociable roles in drug abuse (Parkinson et al., 1999; Fuchs et al., 2004; Ito et al., 2004; Chaudhri et al., 2010). Our results show that PL, BLA, and vSub inputs to NAcC are activated by cocaine cues and not sucrose cues, but only activation of PL neurons that project to NAcC positively correlated with cue-induced reinstatement of cocaine seeking. We also examined whether recruitment of the PL-NAcC pathway occurs in a dopamine-dependent manner as PL neurons that project to NAcC receive input from tyrosine hydroxylase (TH)-positive terminals from VTA (Carr et al., 1999), and dopamine signaling in PL is necessary for drugseeking behavior (McFarland and Kalivas, 2001; See, 2009). We show that pharmacological disconnection of dopamine signaling in PL and glutamate signaling in contralateral NAcC attenuated cue-induced cocaine-seeking, but not sucrose-seeking, behavior. Together, these findings point to a dopamine-PL-NAcC circuit that is uniquely involved in pathological reward seeking associated with addiction.

\section{Materials and Methods}

Subjects

A total of 129 male Sprague Dawley rats $(n=93$, Experiment $1 ; n=36$, Experiment 2; arrival weight 275-325 g; Charles River) were used in these experiments. Rats were single housed under a reverse 12:12 h light cycle in a temperature- and humidity-controlled animal facility with ad libitum access to food and water. All procedures were approved by the Institutional Animal Care and Use Committees of Medical University of South Carolina and Rutgers University and were conducted according to specifications of the Guide for the care and use of laboratory animals (National Research Council, 2011).

\section{Experiment 1}

Intravenous catheter surgery. Rats were anesthetized with ketamine/ xylazine (56.5/8.7 mg/kg, i.p., respectively) and given an analgesic (meloxicam $1 \mathrm{mg} / \mathrm{kg}$ or rimadyl $5 \mathrm{mg} / \mathrm{kg}$, s.c.). Rats conditioned to cocaine were implanted with a chronic indwelling intravenous catheter (made with a modified 22G cannula; Plastics One) into the right jugular vein that exited the body via a biopsy hole on the back. Catheters were flushed with cefazolin $(0.1 \mathrm{ml} ; 100 \mathrm{mg} / \mathrm{ml})$ and heparin $(0.1$ $\mathrm{ml} ; 100 \mathrm{U} / \mathrm{ml}$ ) immediately after surgery, daily beginning $3 \mathrm{~d}$ after surgery, and continuing throughout self-administration training. Rats were allowed to recover for 1 week after surgery before beginning self-administration training.
Injection of retrograde tracer. Immediately following catheter surgery, rats received a unilateral microinjection of cholera toxin $\beta$ subunit $(\mathrm{CTb}$, $\sim 40 \mathrm{nl} ; 0.5 \%$ dissolved in $0.1 \mathrm{M}$ phosphate buffer, Sigma) into NAcC ( $n=52 ; 1.3 \mathrm{~mm}$ rostral to bregma; $1.8 \mathrm{~mm}$ from midline; $7.8 \mathrm{~mm}$ ventral to skull) or NAcSh ( $n=41 ; 1.3 \mathrm{~mm}$ rostral to bregma; $1.0 \mathrm{~mm}$ from midline; $7.8 \mathrm{~mm}$ ventral to skull) using a glass micropipette $(15-20 \mu \mathrm{m}$ diameter tip) and a pneumatic pressure source (Picospritizer; General Valve). Pressure injections were made over a $2 \mathrm{~min}$ period, and pipettes remained in place for $10-15 \mathrm{~min}$ to minimize diffusion along the pipette track.

Cocaine or sucrose self-administration and extinction. The self-administration procedure was similar to previously published studies from our laboratory (Smith et al., 2009; Mahler and Aston-Jones, 2012; Cason and Aston-Jones, 2013; Mahler et al., 2014). Rats were handled daily beginning $3 \mathrm{~d}$ before cocaine or sucrose self-administration training. Self-administration sessions $(2 \mathrm{~h} / \mathrm{d})$ occurred in operant chambers within sound-attenuating boxes, and controlled by Med-PC IV software (Med Associates). Operant chambers were equipped with two retractable levers with cue lights above each lever and a red house light on the opposite wall. Responses on the active lever (fixed ratio-1 schedule) resulted in cocaine infusions $(0.2 \mathrm{mg} / 50 \mu \mathrm{l}$ infusion; cocaine $\mathrm{HCl}$ dissolved in $0.9 \%$ sterile saline, NIDA) or sucrose pellets ( $45 \mathrm{mg}$, Test Diet) paired with discrete cues $(\mathrm{a} 78 \mathrm{~dB}, 2.9 \mathrm{kHz}$ tone and a white cue light above the active lever) during self-administration. After each reward, a 20 s timeout occurred (signaled by turning off the house light) when additional presses did not yield rewards or cues. Presses on the inactive lever were recorded but had no programmed consequences.

After $10 \mathrm{~d}$ of criterion self-administration performance (at least 10 infusions or pellets/session), rats were subjected to extinction training, when responding on either lever had no consequence. Rats received extinction training for a minimum of $7 \mathrm{~d}$ and until they met the criteria of $<25$ active lever presses for 2 or more consecutive days.

Reinstatement and extinction tests. Rats were randomly assigned to either extinction (cocaine: $n=14$, sucrose: $n=9$ ) or reinstatement groups (cocaine $n=20$, sucrose $n=15$ ). Rats selected for the extinction groups were given an additional $2 \mathrm{~h}$ extinction test the day after reaching extinction criteria. Rats in the reinstatement groups were given a single cue-induced reinstatement test on the session after reaching extinction criteria, in which pressing the active lever yielded the cues previously paired with cocaine infusions or sucrose pellets, but no reward. All rats were killed immediately following their $2 \mathrm{~h}$ extinction or reinstatement session. As maximal Fos induction typically occurs at $\sim 90-120 \mathrm{~min}$ following neuronal activation (Müller et al., 1984; Young et al., 1991), Fos labeling here should reflect neural activity near the beginning of the test session (e.g., $\sim 0-30 \mathrm{~min}$ of the test session; see Fig. 1a), the period of peak active lever pressing (Smith et al., 2009; Mahler and Aston-Jones, 2012). Rats that did not acquire criteria performance in behavioral training or reinstatement were excluded from analyses $(n=6)$.

Tissue preparation for immunohistochemistry. Immediately following extinction or reinstatement testing, rats were deeply anesthetized with a ketamine/xylazine mixture and transcardially perfused with $0.9 \%$ saline followed by $4 \%$ PFA. Brains were removed and postfixed for $24 \mathrm{~h}$ in $4 \%$ PFA, then transferred into a $20 \%$ sucrose-azide solution, and stored at $4^{\circ} \mathrm{C}$. Before sectioning, brains were frozen with dry ice, and then cut into $40 \mu \mathrm{m}$ coronal slices on a cryostat. Brain slices were collected in $0.1 \mathrm{M}$ PBS with $1 \%$ sodium azide.

Fos and CTb immunohistochemistry. Fos and CTb dual-labeling immunohistochemistry procedures were similar to previously published methods from our laboratory (Mahler and Aston-Jones, 2012; Sartor and Aston-Jones, 2012; Cason and Aston-Jones, 2013). Sections were quenched with $0.3 \%$ hydrogen peroxide for $15 \mathrm{~min}$, washed $3 \times$ in PBS, and then blocked in a solution of $2 \%$ normal donkey serum and PBS with Triton (PBST) for $2 \mathrm{~h}$. The tissue was then incubated in a normal donkey serum-PBST mixture with rabbit anti-Fos primary antibody (1:2000-1: 2500, Santa Cruz Biotechnology; 1:10,000, Calbiochem) at room temperature for 16-17 h. Sections were washed in PBST, transferred to biotinylated donkey anti-rabbit secondary antibody (1:500, Jackson ImmunoResearch Laboratories) for $2 \mathrm{~h}$, washed, then incubated in avidinbiotin complex (1:500) for $1.5 \mathrm{~h}$, followed by 2 PBST, and one $0.05 \mathrm{M}$ Tris 


\section{a Experiment 1:}

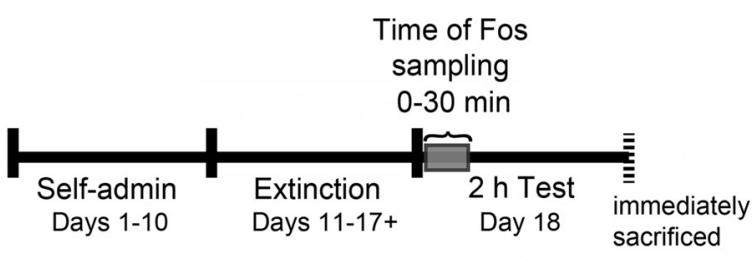

b

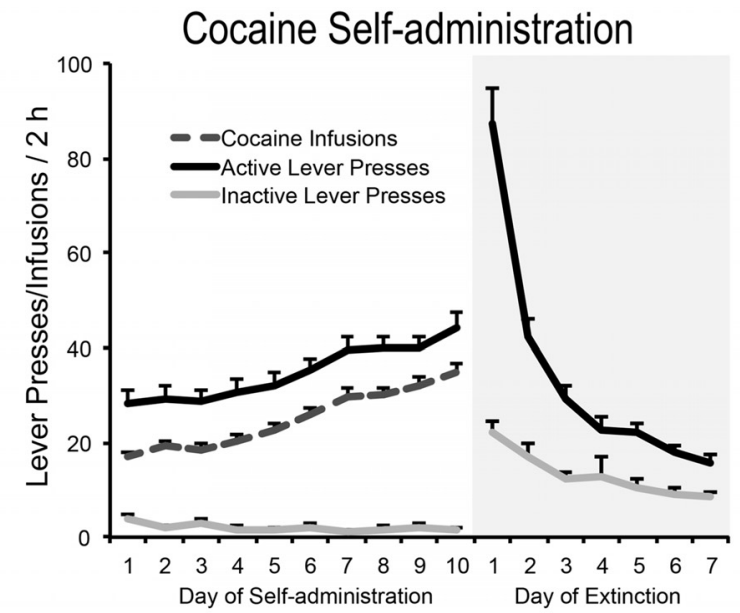

C

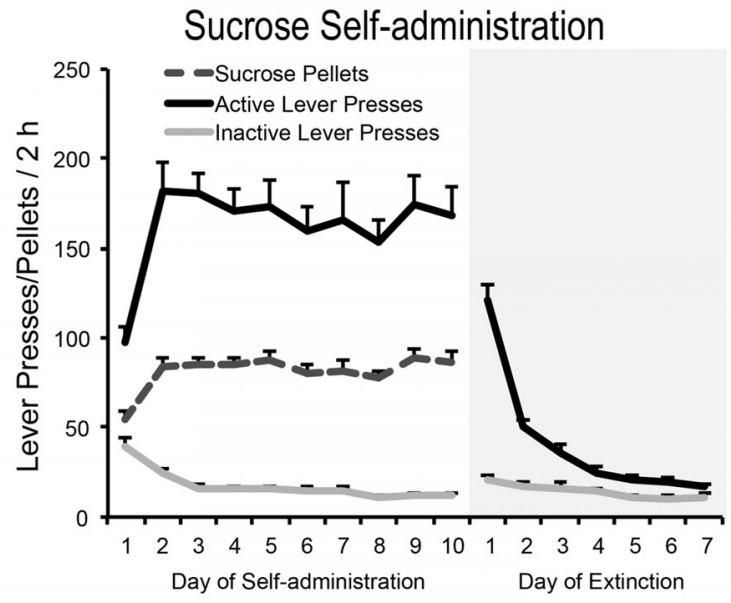

d

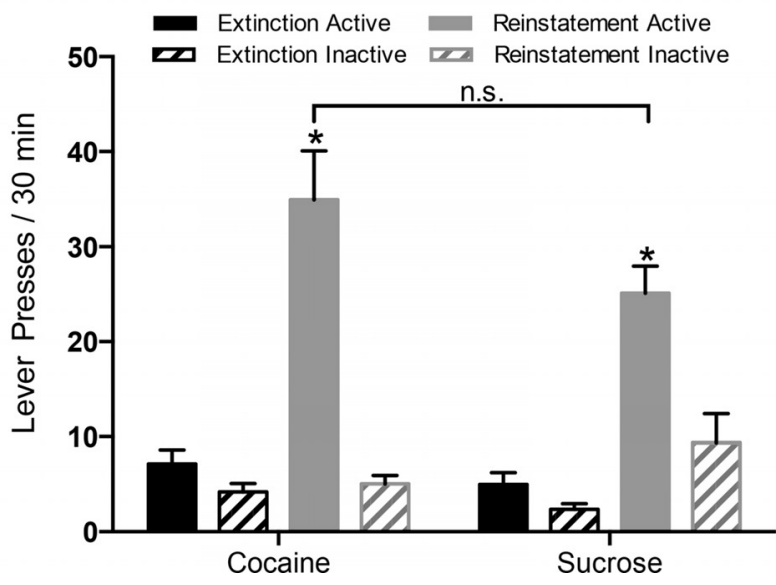

Figure 1. Cocaine and sucrose self-administration, extinction, and reinstatement behavior in rats used in Experiment 1. $\boldsymbol{a}$, Timeline for behavioral procedure. Rats were trained to selfadminister cocaine and extinguish this behavior, then tested for $2 \mathrm{~h}$ in either an additional extinction session or a cue-induced reinstatement session. Rats were killed immediately after testing to stain for Fos, which reflects neural activity at the beginning of the session buffer wash. Sections were then incubated with DAB (Sigma), 0.0002\% $\mathrm{H}_{2} \mathrm{O}_{2}$, and $0.6 \%$ nickel ammonium sulfate in Tris buffer solution to produce a black Fos nuclear stain. Tissue was transferred to Tris buffer to stop the reaction, washed, and transferred to PBS with $1 \%$ sodium azide for $45 \mathrm{~min}$

For subsequent CTb staining, the same tissue was processed with goat anti-CTb primary antibody (1:20,000, List Biological Laboratories) followed by biotinylated donkey anti-goat secondary antibody (1:500, Jackson ImmunoResearch Laboratories). Sections were then incubated in DAB solution without nickel ammonium sulfate to produce the brown $\mathrm{CTb}$ cytoplasmic stain. Brain sections were mounted on glass slides, washed and dehydrated through alcohol and xylenes, and coverslipped with DPX (Sigma).

Fos and CTb quantification. Mounted tissue sections were photographed using Leica microscopes and Stereoinvestigator (MBF Bioscience) or OpenLab (Improvision) software. CTb injection sites in the NAcC and NAcSh were photographed using a $5 \times$ objective and compared with rat brain atlas sections $(1.92 \mathrm{~mm}$ to $1.08 \mathrm{~mm}$ anterior to bregma) (Paxinos and Watson, 2007). Cases in which CTb injections were $>20 \%$ in the adjacent accumbal region $(n=20)$ (e.g., spread into NAcSh for NAcC injections) or in which injections were not in the NAc $(n=8)$ were excluded from analyses. Photographs were also taken of NAcC and NAcSh afferent regions, including $\mathrm{mPFC}(4.20-2.52 \mathrm{~mm}$ anterior to bregma), BLA (1.80-3.24 $\mathrm{mm}$ posterior to bregma), and vSub (5.40-6.36 $\mathrm{mm}$ posterior to bregma). Three tissue sections per rat representing rostral, intermediate, and caudal levels for each brain region (mPFC, BLA, and vSub) in each group (cocaine extinction, cue-induced cocaine reinstatement, sucrose extinction, and cue-induced sucrose reinstatement) were photographed with a $10 \times$ objective and stitched together either automatically using Stereoinvestigator Virtual Slice module or manually using Adobe Illustrator. Sections for each structure were taken at similar levels from bregma to ensure the quantified surface areas were similar across rats. Structure borders were defined based on the rat brain atlas (Paxinos and Watson, 2007).

An observer blind to experimental conditions counted the total number of CTb-labeled neurons (with or without Fos) within the borders of each NAcC or NAcSh afferent structure (mPFC, BLA, and vSub) for each of the three tissue sections per rat. Regions ipsilateral to the CTb injection site were quantified as they tend to have more retrogradely labeled neurons than contralateral connections (Brog et al., 1993). The percentage of $\mathrm{CTb}^{+}$cells that coexpressed Fos was determined for each tissue section. Means of these percentages were computed for each rat, and these per rat means were averaged across behavioral groups for each brain region. One rat was excluded for data $>2.5$ SDs from group means in multiple structures.

\section{Experiment 2}

Intracranial surgery. We used a pharmacological contralateral disconnection approach to examine the functional importance of the PL-NAcC pathway in reinstatement behavior. Rats were implanted with a jugular catheter (as described for Experiment 1) and bilateral guide cannulae (26G, $1.5 \mathrm{~mm}$ center-to-center, Plastics One) directed at PL (3.0 mm from rostral to bregma; $0.75 \mathrm{~mm}$ from midline; $2.9 \mathrm{~mm}$ from skull) and unilateral cannulae (22G, Plastics One) directed at NAcC ( $1.4 \mathrm{~mm}$ rostral to bregma; $1.5 \mathrm{~mm}$ from midline; $5.5 \mathrm{~mm}$ from skull; $10^{\circ}$ angle). Cannuale were attached to the skull using dental cement and four jeweler screws. Rats were allowed 1 week to recover following intracranial surgery before commencing behavioral training.

$(\sim 0-30 \mathrm{~min}) . \boldsymbol{b}$, Behavioral performance during cocaine self-administration and extinction training. c, Behavioral performance during sucrose self-administration and extinction training. $\boldsymbol{d}$, Mean active and inactive lever presses of rats during the first $30 \mathrm{~min}$ of extinction and cue-induced reinstatement test sessions. Active lever responding during cue-induced reinstatement of cocaine and sucrose seeking did not differ at the time Fos was sampled ( $p=0.23$ ). Reinstatement active lever responses were significantly greater than the respective extinction session responses (cocaine: $p<0.0001$; sucrose: $p<0.0001$ ). Error bars indicate SEM. ${ }^{*} p<$ .05. n.s., Not significant. 
a

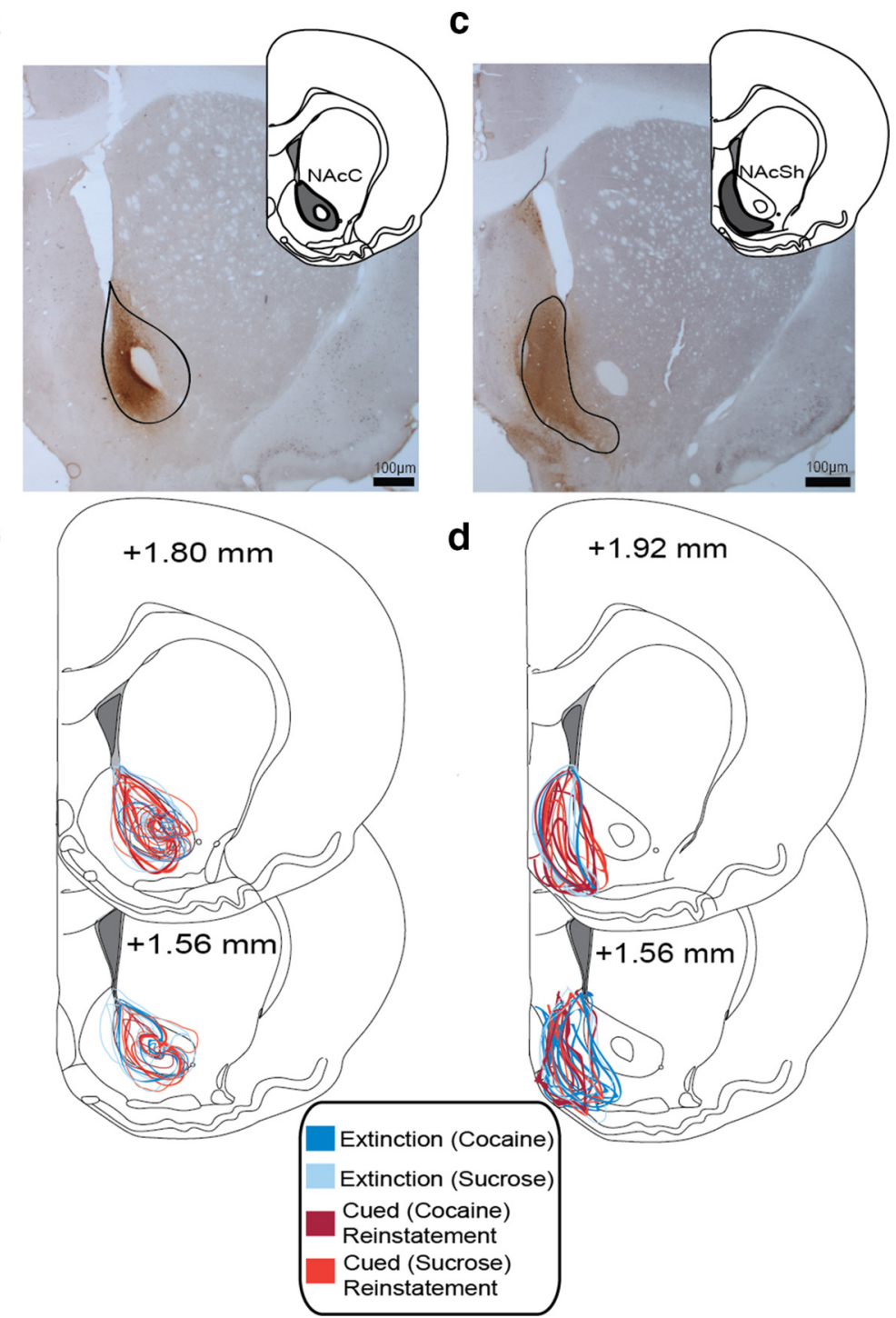

Figure 2. Photomicrographs of retrograde tracer injection sites. $\boldsymbol{a}$, Representative retrograde tracer (CTb) injection in NAcC (brown stain). Black outer line indicates the approximate outer edge of NACC on the coronal section. Scale bar, $100 \mu \mathrm{m}$. Inset, Location of NACC in the rat atlas at $1.80 \mathrm{~mm}$ anterior to bregma (Paxinos and Watson, 2007). $\boldsymbol{b}$, NAcC injection sites plotted across all rats. Colored outlines indicate the outer border of the center of the injection sites for rats in the cocaine extinction group (dark blue lines), cocaine cue-induced reinstatement group (dark red lines), sucrose extinction group (light blue lines), and sucrose cue-induced reinstatement group (light red lines).c, Representative NACSh CTb injection. Black outer line indicates the approximate outer edge of NACSh on the coronal slice. Scale bar, $100 \mu \mathrm{m}$. Inset, Location of NACSh in the rat brain atlas at $1.92 \mathrm{~mm}$ anterior to bregma. $\boldsymbol{d}$, NAcSh injection sites across all rats, illustrated as in $\boldsymbol{b}$. cases, rats received both ipsilateral and contralateral drug treatment, in addition to vehicle, on different days. All rats received three total cued reinstatement tests. The order in which rats received treatment was randomized and counterbalanced.

Locomotor testing. A separate group of rats $(n=8)$ previously trained to self-administer cocaine were assessed for general locomotor activity to ensure that effects of PL or NAcC manipulations on reinstatement behavior were not due to nonspecific motor actions. All rats had previously been part of a cocaine self-administration/reinstatement experiment. At least $7 \mathrm{~d}$ after the final reinstatement tests, rats were placed in locomotor chambers (clear acrylic, $\sim 40 \times 40 \times 30$ $\mathrm{cm}$ ) equipped with Digiscan monitors (AccuScan Instruments) containing a $16 \times 16$ photobeam array for the $x / y$-axis (horizontal activity) and 16 photobeams for the $z$-axis (vertical activity). Photobeam breaks were detected by a Digiscan analyzer and recorded by DigiPro software (version 1.4). Rats were habituated to the locomotor boxes for $2 \mathrm{~d}(2$ $\mathrm{h}$ sessions) before testing. Immediately after the second habituation session, rats were gently restrained and injectors were lowered into PL and NAcC to acclimate them to the microinjection procedure; no injection was made. The next day, rats received microinjections as described above for reinstatement testing, $5 \mathrm{~min}$ before locomotor testing. All rats were tested with microinjections of fluphenazine in PL and AP5/CNQX in contralateral NAcC, and compared with a separate test day when they received vehicle (aCSF) in a similar contralateral fashion. Tests were $2 \mathrm{~d}$ apart and the order in which rats received treatment was randomized and counterbalanced.

Localization of injection sites. Following the final behavioral test, rats were deeply anesthetized with isoflurane, and injectors were once again lowered into both the PL and NAcC. Rats were then decapitated, and brains were flashfrozen in 2-methylbutane and stored at $-80^{\circ} \mathrm{C}$. Brains were sectioned into $40 \mu \mathrm{m}$ sections on a cryostat, mounted, Nissl-stained with neutral red, and coverslipped to localize cannula tract damage and verify injection sites.
Behavioral testing. Rats learned to lever press for cocaine or sucrose and to extinguish this behavior as described in Experiment 1. Immediately following their final extinction session, rats were acclimated to the microinjection procedure: rats were gently restrained and injectors were lowered into PL (33G, Plastics One protruding $1 \mathrm{~mm}$ below cannulae tip) and NAcC (28G, Plastics One, protruding $2 \mathrm{~mm}$ below injector tip) and then removed; no injection was made. The following day, rats underwent reinstatement testing. Five minutes before reinstatement tests, rats received a unilateral infusion of the D1/D2 receptor antagonist fluphenazine $(33.3 \mathrm{~mm})$ into PL and a unilateral infusion of the AMPA/NMDA receptor antagonist mixture AP-5/ CNQX $(33.8 / 3.3 \mathrm{~mm})$ into ipsilateral $(n=8)$ or contralateral NAcC $(n=11)$, or infused with vehicle (aCSF) in a similar fashion. Rats received at least 2 additional days of extinction $(<25$ active lever presses) before undergoing an additional reinstatement test (Smith et al., 2009; Mahler and Aston-Jones, 2012). All rats received vehicle and either ipsilateral or contralateral PL-NAcC drug treatments. In some

\section{Data analyses}

In Experiment 1, unpaired samples $t$ tests were used to analyze all projections to NAcC or NAcSh. We compared the percentages of $\mathrm{CTb}^{+}$ neurons that were also $\mathrm{Fos}^{+}$for extinction versus reinstatement for cocaine-trained rats, and separately for sucrose-trained rats. Correlations between the percentages of $\mathrm{CTb}$ neurons that were also $\mathrm{Fos}^{+}$and active lever presses during the first $30 \mathrm{~min}$ of reinstatement test sessions were obtained using a Pearson's correlation coefficient test. Alpha was set to 0.05 . A Mann-Whitney test was used to compare extinction versus reinstatement, and cocaine versus sucrose lever pressing during the first $30 \mathrm{~min}$ of the test sessions, due to unequal variance between groups.

Given the established role of PL and BLA projections to NAcC in cocaine seeking (Di Ciano and Everitt, 2004; Kufahl et al., 2009; Stefanik and Kalivas, 2013; Martín-García et al., 2014; Zhou et al., 2014; Stefanik et al., 2016), we predicted a priori that Fos activation of NAcC-projecting PL and BLA neurons during cue-induced reinstatement would correlate positively with cocaine seeking. Therefore, we used one-tailed Pearson 
tests to measure correlations between behavior and Fos expression in PL and BLA neurons that project to NAcC. In all other cases, two-tailed Pearson tests were used.

In Experiment 2, reinstatement behavior (in terms of both active and inactive lever responding) was indistinguishable between rats that received ipsilateral versus contralateral infusions of vehicle; therefore, data from these rats were pooled to create a single vehicle control group. Active and inactive lever responding during cue-induced reinstatement for both cocaine and sucrose was compared across treatment groups using one-way ANOVA and subsequent post hoc tests where appropriate. To examine the overall distance traveled (measured in centimeters), and horizontal and vertical beam breaks during the locomotor test, paired-sample $t$ tests were used. To examine any effect of treatment over the course of the locomotor test, we used a two-way ANOVA with treatment $\times$ time factors. Graphpad Prism version 6 was used for all statistical analyses, and an $\alpha$ value of 0.05 was adopted for all statistical tests.

\section{Results}

Experiment 1: identification of accumbal inputs that are activated during cue-induced reinstatement of cocaine seeking or sucrose seeking

\section{Self-administration and extinction training}

All rats showed stable self-administration and extinction learning. For behavioral analyses, we combined self-administration data for NAcC- and NAcSh-injected rats as the number of rewards and lever presses for rewards did not differ during training (two-way repeated-measures ANOVA, structure $X$ day; cocaine infusions: $\left.F_{(1,32)}=0.2, p>0.05\right)$; sucrose pellets: $\left(F_{(1,22)}=0.6\right.$, $p>0.05)$; lever presses for cocaine: $\left.F_{(1,32)}=0.1, p>0.05\right)$; lever presses for sucrose: $\left.F_{(1,22)}=0.1, p>0.05\right)$. Both cocaine- and sucrose-trained rats decreased lever pressing over days during extinction training (Fig. $1 b, c$; repeated-measures ANOVA; Tukey post hoc across cocaine extinction days; $F_{(6,33)}=78.4, p<0.0001$; across sucrose extinction days; $\left.F_{(6,23)}=89.8, p<0.0001\right)$. Rats allocated to reinstatement and extinction groups were similar in all aspects of self-administration behavior ( $p$ values $>0.05$; data not shown).

\section{Reinstatement and extinction tests}

Rats showed reliable cue-induced reinstatement behavior. Both cocaine- and sucrose-trained rats increased pressing during the reinstatement test session compared with the average of their prior 2 extinction days (paired $t$ test; cocaine: $t_{(19)}=5.6, p<$ 0.0001 ; sucrose: $\left.t_{(14)}=9.9, p<0.0001\right)$. Similarly, rats subjected to cue-induced reinstatement of cocaine or sucrose seeking showed significantly greater active lever responding than rats that received an extinction test session instead (Mann-Whitney, cocaine: $\mathrm{U}=12.5, \mathrm{n}_{1}=14, \mathrm{n}_{2}=20, p<0.0001$; sucrose: $\mathrm{U}=5$, $\left.\mathrm{n}_{1}=13, \mathrm{n}_{2}=16, p<0.0001\right)$. Active lever pressing was statistically similar in cocaine and sucrose rats during the first $30 \mathrm{~min}$ of extinction (unpaired $t$ test, $\mathrm{t}_{(25)}=1.1, p>0.05$ ) or reinstatement sessions (the time of maximal drug seeking, corresponding to Fos measurements; Mann-Whitney, $\mathrm{U}=121.5, \mathrm{n}_{1}=20, \mathrm{n}_{2}=16$, $p>0.05$; Fig. $1 d$ ). This indicates that differences in Fos induction among groups (reported below) were not confounded by differences in motor activity. Reinstatement pressing was significantly greater on the active (reward-associated) lever compared with the inactive lever (paired $t$ test; cocaine: $t_{(19)}=6.0, p<0.0001$; sucrose: $\left.t_{(15)}=4.1, p=0.001\right)$.

\section{CTb injection sites}

The center of the injection sites for NAcC (Fig. 2a,b) and NAcSh (Fig. 2c,d) ranged between $1.92 \mathrm{~mm}$ and $1.08 \mathrm{~mm}$ anterior to bregma. NAcC injections were located in the central NAcC and
Table 1. Afferents to NAcC and NAcSh ${ }^{a}$

\begin{tabular}{lrrrr}
\hline & \multicolumn{3}{l}{ CTb cells/slice } & NAcSh \\
\cline { 2 - 5 } & NAcC & & Mean & SEM \\
\hline Structure & Mean & SEM & 42 & 8 \\
PL & $93^{*}$ & 14 & 61 & 6 \\
IL & 72 & 12 & 86 & 12 \\
BLA & $200^{*}$ & 23 & $291^{*}$ & 40 \\
VSub & 65 & 13 & & \\
\hline
\end{tabular}

${ }^{a}$ Mean CTb-labeled cells per slice for PL, IL, BLA, and vSub projections to NAcC and NAcSh. Values represent the mean \pm SEM number of neurons in PL, LL, BLA, and vSub that are retrogradely labeled from either NAcC or NACSh. ${ }^{*} p<0.05$, stronger projection target (either NAcC or NACSh) of PL, IL, BLA, or vSub structures using a multiple $t$ test correction (PL: $t_{(56)}=3.1, p=0.0035 ; \mathrm{lL}: t_{(56)}=0.8, p>0.05 ; \mathrm{BLA}: t_{(56)}=4.2, p=0.0001 ;$ vSub: $t_{(56)}=5.7$ $p<0.0001$ ). Each projection to NAcC: $n=31$ rats ( 3 brain sections per rat averaged). Each projection to NAcSh: $n=$ 27 rats ( 3 brain sections per rat averaged).

generally surrounded the anterior commissure, spreading $\sim 1$ $\mathrm{mm}$ anteroposteriorly. NAcSh injections were located in the medial portion of the structure and spread $\sim 2 \mathrm{~mm}$ dorsoventrally and $\sim 1 \mathrm{~mm}$ anteroposteriorly.

\section{Patterns of NAcC and NAcSh afferents}

The relative strengths of PL, IL, BLA, and vSub projections to $\mathrm{NAcC}$ or NAcSh (as revealed by the mean \pm SEM of retrogradely labeled neurons; Table 1) were consistent with previous findings (Groenewegen et al., 1987, 1999; Brog et al., 1993; Vertes, 2004). As shown in Table 1, there were relatively more projections from $\mathrm{PL}$ and BLA to NAcC than to NAcSh, and more projections from vSub to NAcSh than to NAcC (PL: $t_{(56)}=3.05, p=0.0035$; BLA: $t_{(56)}=4.2, p=0.0001$; vSub: $\left.t_{(56)}=5.7, p<0.0001\right)$. There were no differences in the number of IL neurons that project to NAcC compared with NAcSh $\left(\mathrm{t}_{(56)}=0.7, p>0.05\right)$. Figure 3 includes representative brain sections for $\mathrm{CTb}^{+}$(projections to NAcC, brown stain), Fos $^{+}$(black nuclear stain), and doubly labeled neurons ( $\mathrm{Fos}^{+} \mathrm{CTb}$; arrows).

\section{Activation of prelimbic cortex inputs to NAcC during cocaine seeking}

Many neurons in mPFC express Fos during cue-induced reinstatement, but these activated neurons do not project to VTA (Kufahl et al., 2009; Mahler and Aston-Jones, 2012). Here, we found that many of these neurons instead project to NAcC. In particular, a greater percentage of PL neurons retrogradely labeled from NAcC expressed Fos during cue-induced reinstatement of cocaine seeking compared with extinction of cocaine self-administration (Fig. $4 a ; t_{(15)}=2.8, p=0.0142$ ). Similar analyses for sucrose-trained rats revealed no differences between reinstatement and extinction in the percentage of PL neurons retrogradely labeled from NAcC that were also $\mathrm{Fos}^{+}$(Fig. 4b; $\left.t_{(12)}=1.3, p>0.05\right)$. Further, the percentages of $\mathrm{CTb}^{+}$neurons in PL that were also $\mathrm{Fos}^{+}$correlated positively with active lever pressing during the first $30 \mathrm{~min}$ of cue-induced reinstatement of cocaine seeking (Fig. 4e; Pearson correlation, $n=10, r=0.60$, $p=0.0334$ ), but not with lever pressing during the same period of cue-induced reinstatement of sucrose seeking (Fig. 4f; Pearson correlation, $n=9, r=0.08, p>0.05$ ).

In contrast, the percentages of NAcC-projecting IL neurons that were also Fos ${ }^{+}$did not differ between cue-induced reinstatement and extinction of cocaine seeking (Fig. $4 a ; t_{(15)}=0.2, p>$ 0.05 ), or between cue-induced reinstatement and extinction of sucrose-seeking (Fig. $4 b ; t_{(12)}=1.9, p>0.05$ ). Additionally, there were no correlations between the percentage of $\mathrm{Fos}^{+}$IL neurons retrogradely labeled from $\mathrm{NAcC}$ and active lever pressing during 
a

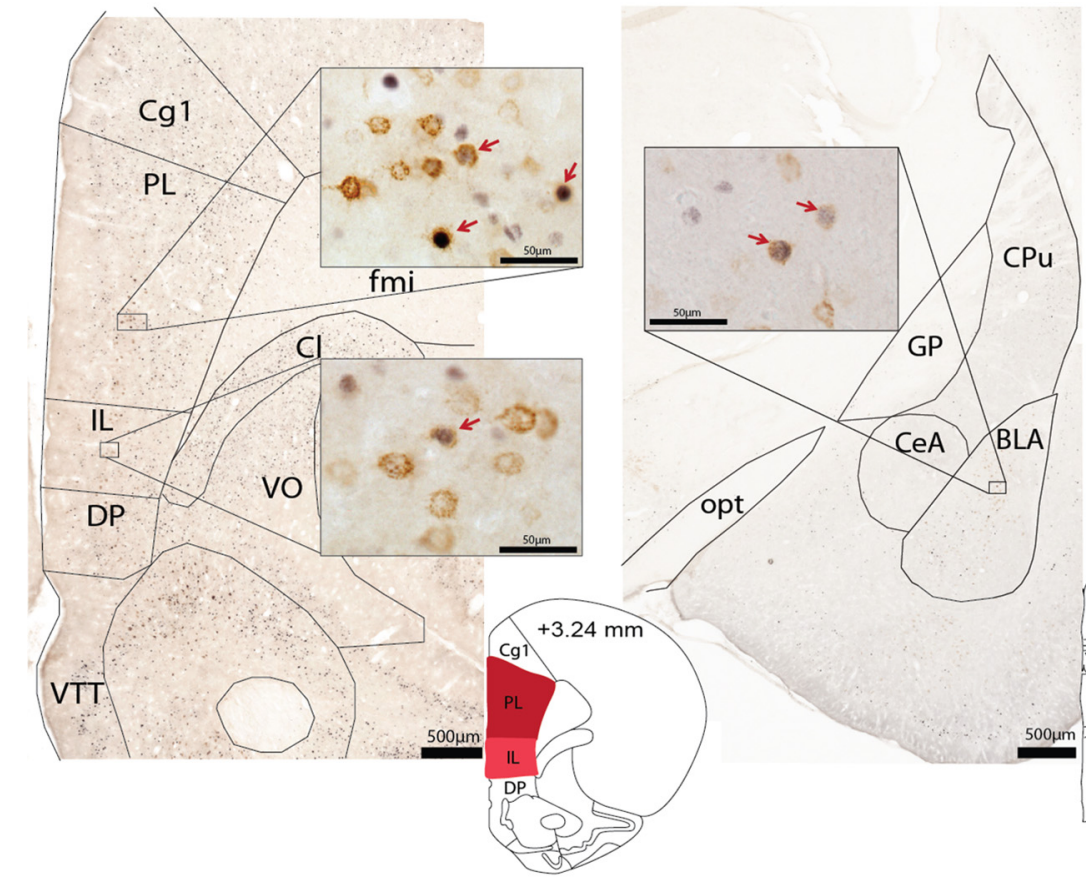

C

Figure 3. Photomicrographs of retrogradely labeled neurons from NAcC. $a, \mathrm{mPFC}$ brain section with magnified photomicrographs (insets) of CTb ${ }^{+}$neurons retrogradely labeled from NAcC (brown stain), Fos $^{+}$neurons (blacknuclear stain), and dual-labeled (Fos ${ }^{+} / \mathrm{CTb}^{+}$) cells (red arrows) in PL and IL cortices. Rat atlas coronal section inset represents the location of PL and IL cortices (highlighted in red) at $3.24 \mathrm{~mm}$ anterior to bregma as seen in the Paxinos and Watson (2007). Cg1, Cingulate cortex; PL, prelimbic region of the medial prefrontal cortex; IL, infralimbic region of the medial prefrontal cortex; DP, dorsal peduncular cortex; VTT, ventral tenia tecta; fmi, forceps minor of the corpus callosum; $\mathrm{Cl}$, claustrum; $\mathrm{V0}$, ventral orbital cortex. $\boldsymbol{b}$, BLA brain section with magnified photomicrographs (insets) of CTb ${ }^{+}$neurons retrogradely labeled from NAcC, Fos ${ }^{+}$neurons, and dual-labeled (Fos ${ }^{+} / \mathrm{CTb}^{+}$) cells illustrated as in $a$. Rat atlas coronal section inset represents the location of BLA (highlighted in yellow) at $2.52 \mathrm{~mm}$ posterior to bregma. CPu, Caudate-putamen; GP, globus pallidus; (eA, central amygdala; opt, optic tract. c, vSub brain section with magnified photomicrographs (insets) of CTb ${ }^{+}$neurons retrogradely labeled from NAcC, Fos ${ }^{+}$neurons, and dual-labeled (Fos ${ }^{+} / \mathrm{CTb}^{+}$) cells illustrated as in $\boldsymbol{a}$. Rat atlas coronal section inset represents the location of vSub (highlighted in blue) at $6.12 \mathrm{~mm}$ posterior to bregma. vCA1, Ventral CA1 region of the hippocampus; DS, dorsal subiculum. Scale bars: mPFC, BLA, vSub coronal sections, $500 \mu \mathrm{m}$; insets, $50 \mu \mathrm{m}$.

the first $30 \mathrm{~min}$ of reinstatement for cocaine- or sucrose-trained rats (Pearson correlations; Table 2).

Fos expression during extinction compared with reinstatement of cocaine seeking did not differ in PL or IL projections to NAcSh (Fig. $4 c$; PL: $t_{(15)}=1.95$; IL: $t_{(15)}=0.4$, $p$ values $>0.05$ ). The same result was seen with extinction and reinstatement of sucrose seeking (Fig. $4 d$; PL: $t_{(8)}=0.5$; IL: $t_{(8)}=0.9, p$ values $>$ $0.05)$. There were also no correlations between Fos induction and reinstatement of cocaine- or sucrose-seeking in PL or IL projections to NAcSh (Pearson correlations; Table 2).

These results indicate that PL projections to NAcC, but not to $\mathrm{NAcSh}$, were recruited during, and in proportion to, cue-induced cocaine-seeking behavior. Additionally, PL neurons that project to NAcC did not show similar results during cue-induced sucrose seeking.

\section{Activation of BLA and ventral subiculum projections to nucleus accumbens core and shell during cocaine seeking versus sucrose seeking}

BLA and vSub provide substantial glutamate input to NAc (Groenewegen et al., 1987, 1999). Therefore, given the importance of glutamate inputs to NAc in drug-seeking behavior (Everitt et al., 1999; Kalivas, 2009; Britt et al., 2012; Floresco, 2015), we examined whether BLA and vSub inputs to NAc also express Fos during conditioned cocaine seeking. We found that BLA and vSub neurons that project to NAcC expressed a greater proportion of $\mathrm{Fos}^{+}$cells during cue-induced reinstatement of cocaine seeking relative to extinction (Fig. $4 a$; BLA: $t_{(15)}=2.7, p=0.0181$; vSub: $\left.t_{(15)}=2.1, p=0.0498\right)$. There were no such differences between extinction and cue-induced reinstatement of sucrose seeking in NAcC-projecting BLA or vSub neurons (Fig. $4 b$; BLA: $t_{(12)}=0.3$, vSub: $t_{(12)}=1.1, p$ values $\left.>0.05\right)$. The percentages of $\mathrm{Fos}^{+}$BLA or vSub neurons retrogradely labeled from NAcSh did not differ between cocaine extinction and cue-induced reinstatement of cocaine seeking (Fig. $4 c$; BLA: $t_{(15)}=0.4$, vSub: $t_{(15)}=0.5, p$ values $>0.05)$, or between sucrose extinction and cue-induced reinstatement of sucrose seeking (Fig. $4 d$; BLA: $t_{(8)}=0.5$, vSub: $t_{(8)}=0.7, p$ values $\left.>0.05\right)$. In contrast to the PL-NAcC circuit, the percentages of $\mathrm{Fos}^{+}$BLA or vSub neurons retrogradely labeled from NAcC or NAcSh did not correlate with reinstatement of cocaine seeking (Pearson correlations; Table 2). Additionally, there were no correlations between Fos induction and reinstatement of sucrose seeking in BLA or vSub projections to NAcC or NAcSh (Table 2).

In summary, our findings showed that BLA and vSub projections to NAcC (but not to NAcSh) were activated during cueinduced cocaine seeking, but not sucrose seeking. However, unlike PL projections to NAcC, this Fos activation did not correlate with the intensity of cocaine-seeking behavior.

\section{Experiment 2: causal role of a dopamine-PL-NAcC circuit in cue-induced reinstatement of cocaine seeking versus sucrose seeking Self-administration and extinction behavior}

Results from Experiment 1 indicated that the PL-NAcC pathway is activated by cocaine cues and is uniquely correlated with reinstatement behavior. To test the functional importance of this pathway, and to test the hypothesis that this 
a

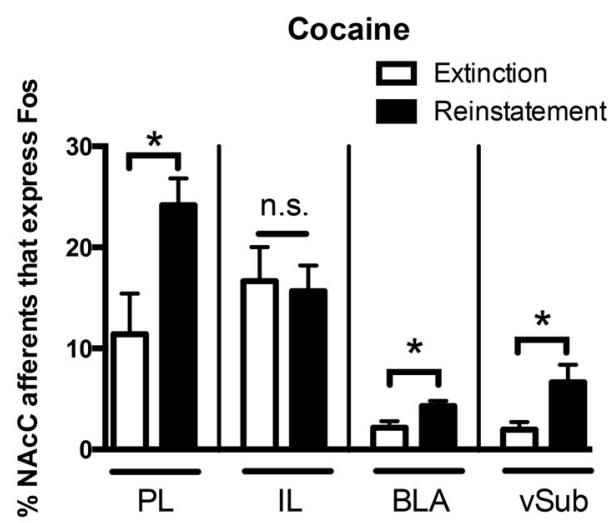

C

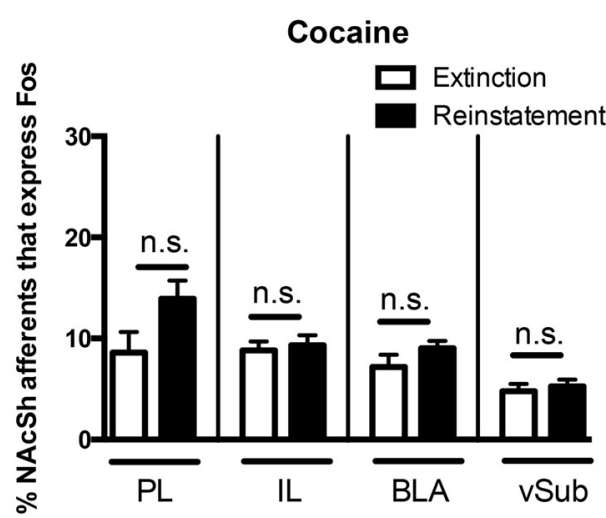

e

b

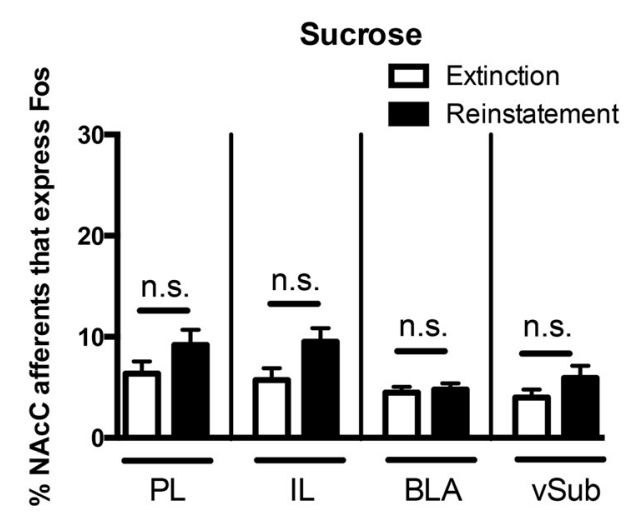

d

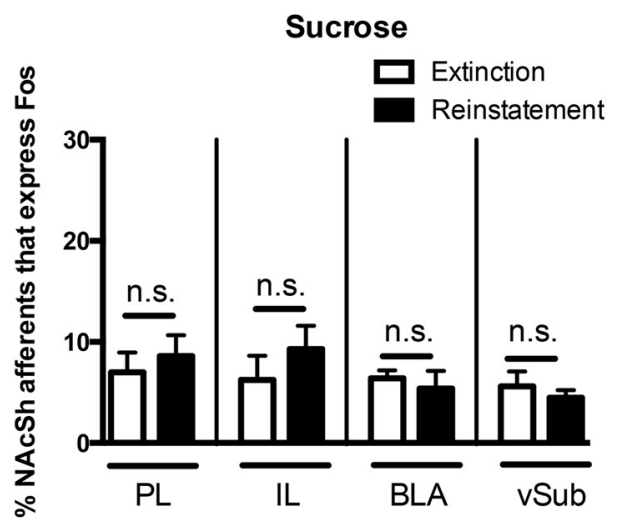

f

\section{PL to NAcC}

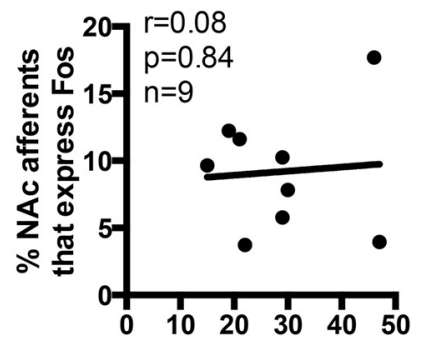

Active Lever Presses

(0-30 mins in sucrose reinstatement)

Figure 4. PL neurons that project to NACC activate in proportion to cocaine seeking, but not sucrose seeking. $\boldsymbol{a}$, PL neurons retrogradely labeled from NAcC expressed a significantly greater percentage of Fos during cue-induced reinstatement of cocaine seeking (black bar, $n=10$ ) compared with extinction of cocaine seeking (white bar, $n=7$ ). There were no differences in the percentage of Fos in the IL-NACC projection during extinction $(n=7)$ versus cue-induced reinstatement of cocaine seeking $(n=10)$. Similar to the PL-NAcC pathway, BLA and vSub neurons that are retrogradely labeled from NAcC showed significantly greater percentages of Fos during cue-induced reinstatement of cocaine seeking $(n=10)$ compared with extinction $(n=7)$. $\boldsymbol{b}$, There were no differences in the percentage of Fos in the PL-NAcC projection during extinction (white bar, $n=5$ ) and cue-induced reinstatement of sucrose seeking (black bar, $n=9$ ). The percentages of Fos ${ }^{+}$ IL, BLA, or vSub neurons that were retrogradely labeled from NAcC also did not differ between extinction $(n=5)$ and cue-induced reinstatement sucrose seeking $(n=9)$. $c$, The percentages of Fos ${ }^{+}$ PL, IL, BLA, or vSub neurons that were retrogradely labeled from NAcSh did not differ between extinction (white bars, $n=7$ ) and cue-induced reinstatement of cocaine seeking (black bars, $n=10$ ). $\boldsymbol{d}$, The percentages of Fos ${ }^{+}$PL, IL, BLA, or vSub neurons that were retrogradely labeled from NAcSh did not differ between extinction (white bars, $n=4$ ) and cue-induced reinstatement of sucrose seeking (black bars, $n=6$ ). $\boldsymbol{e}$, The percentages of Fos ${ }^{+} \mathrm{PL}$ neurons retrogradely labeled from NAcC during cue-induced reinstatement of cocaine seeking correlated with the first 30 min of active lever pressing in individual rats (circles, $n=10)$. However, Fos activation in the same circuit did not correlate with cue-induced reinstatement of sucrose seeking $(\boldsymbol{f}, n=9)$. Bar graphs and error bars indicate mean \pm SEM. ${ }^{*} p<0.05$. n.s., Not significant.

pathway is recruited in a dopamine-dependent manner, we used a pharmacological disconnection approach whereby dopamine signaling was blocked in PL and glutamate signaling was blocked in the contralateral NAcC.

Rats were trained to self-administer cocaine and underwent extinction training in a similar manner to those de- scribed in Experiment 1 (Fig. 5). Groups were statistically similar in terms of number of days taken to acquire selfadministration, average number of active and inactive lever presses during training, and the total number of infusions earned over the $10 \mathrm{~d}$ self-administration period ( $p$ values $>$ 0.05; data not shown). Similarly, groups in Experiment 1 vs 
Table 2. Correlations between Fos + NAcC and NAcSh afferents and reinstatement: reinstatement active lever presses by $\%$ Fos $+\mathrm{CTb}$ cells $^{a}$

\begin{tabular}{|c|c|c|c|c|c|c|c|}
\hline \multirow[b]{2}{*}{ Reward } & \multirow[b]{2}{*}{ Structure } & \multicolumn{3}{|l|}{$\mathrm{NACC}$} & \multicolumn{3}{|l|}{ NAcSh } \\
\hline & & $r$ value & $n$ & $p$ value & $r$ value & $n$ & $p$ value \\
\hline \multirow[t]{4}{*}{ Cocaine } & $P L$ & 0.60 & 10 & $0.03^{*}$ & -0.12 & 10 & 0.73 \\
\hline & IL & 0.28 & 10 & 0.44 & 0.17 & 10 & 0.65 \\
\hline & BLA & 0.28 & 10 & 0.22 & 0.11 & 10 & 0.76 \\
\hline & vSub & 0.40 & 10 & 0.25 & -0.19 & 10 & 0.59 \\
\hline \multirow[t]{4}{*}{ Sucrose } & $P L$ & 0.08 & 9 & 0.84 & 0.24 & 6 & 0.65 \\
\hline & IL & -0.49 & 9 & 0.18 & -0.48 & 6 & 0.33 \\
\hline & BLA & -0.28 & 9 & 0.46 & 0.77 & 6 & 0.07 \\
\hline & vSub & -0.55 & 9 & 0.12 & -0.50 & 6 & 0.31 \\
\hline
\end{tabular}

${ }^{a}$ Correlations of Fos in NAcC and NACSh afferent neurons with active lever responding during cue-induced reinstatement of cocaine or sucrose seeking. Correlation coefficients represent the relationships between the percentages of Fos induction in NACC or NACSh afferent neurons and active lever pressing during the first $30 \mathrm{~min}$ of cue-induced cocaine or sucrose seeking. The $0-30 \mathrm{~min}$ active lever responding reflects the time of peak Fos induction. ${ }^{*} p<0.05$; Pearson $r$ correlation.

\section{a Experiment 2:}

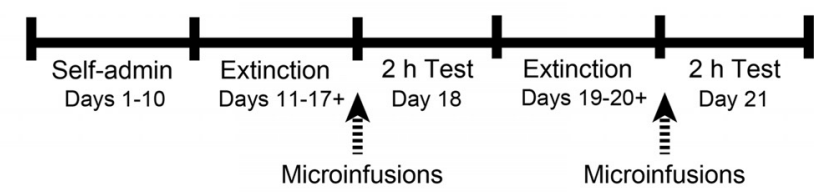

b

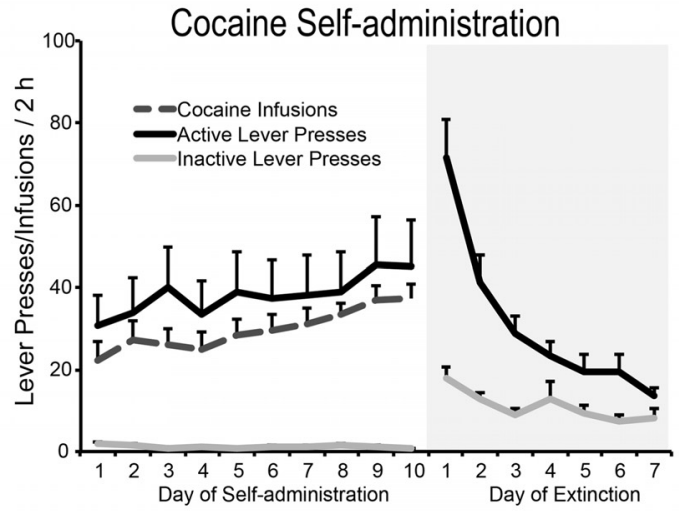

C

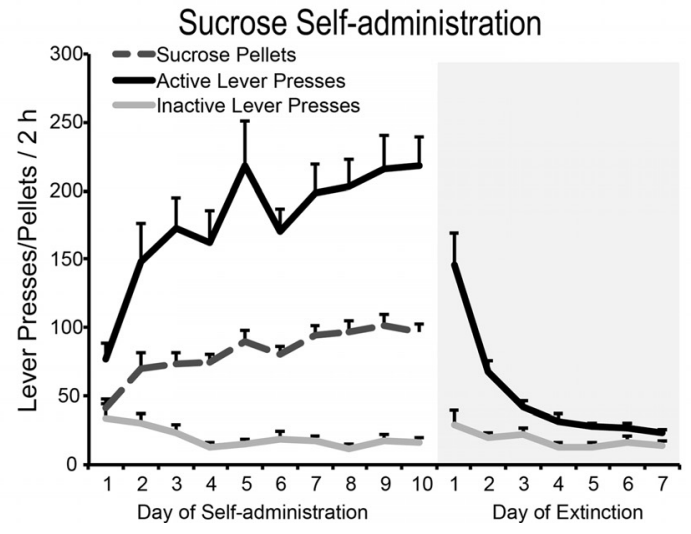

Figure 5. Cocaine and sucrose self-administration, extinction, and reinstatement behavior in rats used in Experiment 2. $\boldsymbol{a}$, Timeline for behavioral procedure. Rats were trained to selfadminister either cocaine or sucrose before undergoing extinction training. Immediately before cue-induced reinstatement testing, rats received microinfusions of fluphenazine in PL and AP5/ CNQX in the NAcC, or vehicle (aCSF) in both sites. Infusions in the NAcC were made in either the ipsilateral (IPSI) or contralateral (CONTRA) hemisphere to the PL infusion. Lever pressing behavior was reextinguished, and rats were tested for reinstatement behavior following an additional microinfusion drug treatment (counterbalanced within-subject design). $\boldsymbol{b}$, Behavioral performance during cocaine self-administration and extinction training. $c$, Behavioral performance during sucrose self-administration and extinction training.
Experiment 2 did not differ in terms of days taken to reach extinction criterion ( $p>0.05$; data not shown).

Pharmacological disconnection of the dopamine-PL-NAcC pathway attenuated cue-induced reinstatement of cocaine seeking, but not sucrose seeking

Results from Experiment 1 found specific neural activation in the PL-NAcC pathway during cue-induced reinstatement of cocaine seeking. Because NAcC-projecting PL neurons are innervated by dopamine neurons in VTA and are responsive to dopamine, we examined whether the PL-NAcC pathway is modulated by dopamine to drive cued cocaine seeking. For this, we used a pharmacological disconnection method to block dopamine signaling unilaterally in PL as well as glutamate signaling in the contralateral NAcC, immediately before testing for cued reinstatement of cocaine seeking (Fig. 6a). A one-way ANOVA revealed an effect of treatment on reinstatement $\left(F_{(3,45)}=20.3, p<0.0001\right)$. Unilateral microinjections of fluphenazine in PL, and AP5/CNQX in the contralateral NAcC significantly attenuated reinstatement of active lever responding, compared with ipsilaterally treated controls $\left(t_{(45)}=2.2, p=0.0364\right.$; Fig. $\left.6 b\right)$. We also made unilateral PL and NAcC microinjections ipsilaterally as a control, and separate analyses suggested that these injections did not affect reinstatement behavior relative to vehicle-treated controls $\left(t_{(45)}=1.6\right.$, $p>0.05)$. There was no effect of treatment on inactive lever responding $\left(F_{(3,45)}=0.6, p>0.05\right)$. Because results from Experiment 1 indicated that the PL-NAcC pathway is not recruited during cue-induced sucrose seeking, we expected that blocking dopamine in PL and glutamate in the contralateral NAcC would not affect this behavior. Indeed, we saw no effect of contralateral PL-fluphenazine and NAcC-AP5/CNQX microinjections on active lever responding during cued reinstatement of sucrose seeking relative to vehicle treatments $\left(t_{(27)}=0.8, p>0.05\right.$; Fig. $\left.6 d\right)$. These results confirm that the PL-NAcC pathway is uniquely involved in cue-induced reinstatement of cocaine seeking and that this pathway is recruited in a dopamine-dependent manner.

\section{Pharmacological disconnection of the dopamine-PL-NAcC} pathway does not affect general locomotor behavior

We next assessed whether there were any nonspecific motor effects of disconnecting the dopamine-PL-NAcC pathway. Rats were treated unilaterally with fluphenazine in PL and AP5/ CNQX in the contralateral NAcC, or vehicle in each site, immediately before testing general locomotor activity in $2 \mathrm{~h}$ test sessions. There was no effect of contralateral PL-fluphenazine plus NAcC-AP5/CNQX treatment on either horizontal $(p>.05)$ or vertical $(p>.05)$ activity over the $2 \mathrm{~h}$ test session (Fig. $7 b, c)$. Despite there being a trend toward a significant time $\times$ treatment interaction for distance traveled during the test session, this effect also failed to reach significance (Fig. $7 d ; p>0.05$ ).

\section{Histology}

Figure $6 c, e$ illustrates all microinjection sites for cocaine and sucrose rats. Microinjections made into PL ranged from 3.42 to $2.92 \mathrm{~mm}$ anterior to bregma. Microinjections made into NAcC were located between 1.44 and $2.76 \mathrm{~mm}$ anterior to bregma. One rat from the cocaine group and two rats from the sucrose group were excluded from reinstatement analyses due to misplaced cannulae.

An illustration of all microinjection sites for rats used for locomotor assessment is shown in Figure 7a. Microinjection placements were similar to those for reinstatement tests. 


\section{Discussion}

We investigated the proportion of NAcprojecting neurons originating from $\mathrm{PL}$, IL, BLA, and vSub that were activated in response to cocaine cues. Our results showed that, within PL, BLA, and vSub, only those cells that project to the NAcC (not the NAcSh) exhibited increased Fos protein in response to cocaine conditioned stimuli. Further, only Fos activation in NAcC-projecting PL neurons positively correlated with the magnitude of cocaine reinstatement behavior. To test the functional importance of the PLNAcC pathway, and of dopamine signaling in that pathway, we pharmacologically disconnected the dopamine-PL-NAcC pathway immediately before reinstatement testing. This manipulation prevented cued reinstatement of cocaine seeking, but not sucrose seeking, indicating a specific role for a dopamine-PLNAcC pathway in reinstatement of drug seeking.

\section{Activated circuits target NAcC, not NAcSh}

Prelimbic, BLA, and vSub neurons that expressed Fos predominately targeted NAcC, and not NAcSh, during cue-induced reinstatement of cocaine seeking. Many studies have implicated NACC as a central region necessary for discrete, response-contingent cue-induced cocaine seeking (Fuchs et al., 2004; Bäckström and Hyytiä, 2007), whereas projections to NAcSh are important for other drugs of abuse (e.g., heroin) and reinstatement elicited by drug-associated discriminative contexts (Bossert et al., 2007, 2012; Cruz et al., 2014). For example, neural responses to cocaine-conditioned cues are heightened in NAcC, but not NAcSh, following prolonged abstinence (Hollander and Carelli, 2007). Further, inactivation of NAcC blocks cue-induced cocaine seeking, whereas inactivation of NAcSh has no such effect (Fuchs et al., 2004). Our current results support previous literature concerning the importance of NAcC in cocaine seeking in response to discrete cues, and further elucidate addictionrelated projection targets from activated neuronal subpopulations within brain structures.

\footnotetext{
Multiple NAcC afferents express Fos during cocaine seeking to conditioned cues

Multiple glutamatergic inputs interact to modulate NAc activity (Mulder et al., 1998; Stern et al., 1998; McGinty and Grace, 2009; Calhoon and O'Donnell, 2013). For example, in anesthetized rats, $\mathrm{mPFC}$ stimulation only induces NAc firing when combined with hippocampal activation (O'Donnell and Grace, 1995). Additionally, input from multiple glutamatergic
}

b bars indicate SEM.
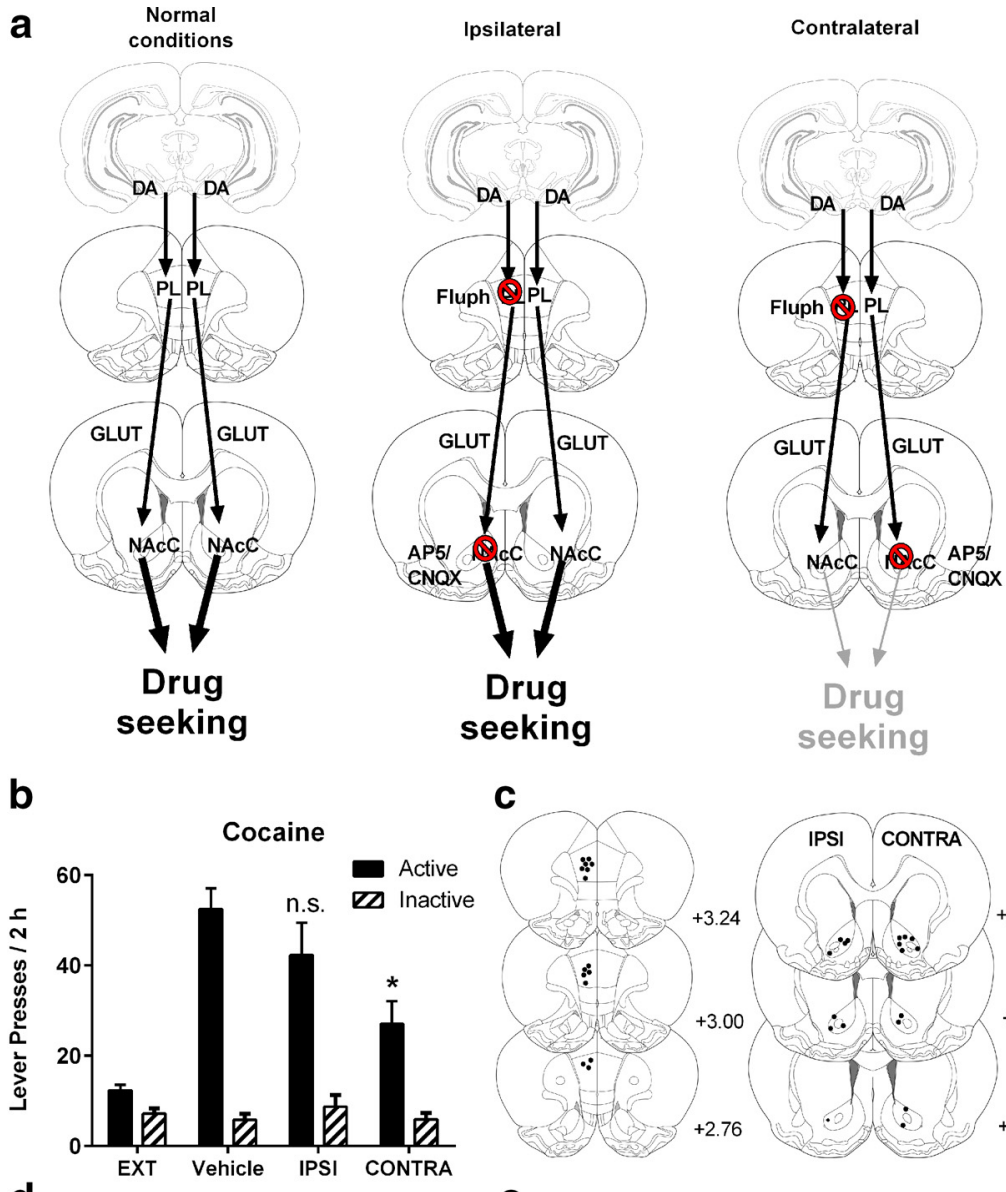

C
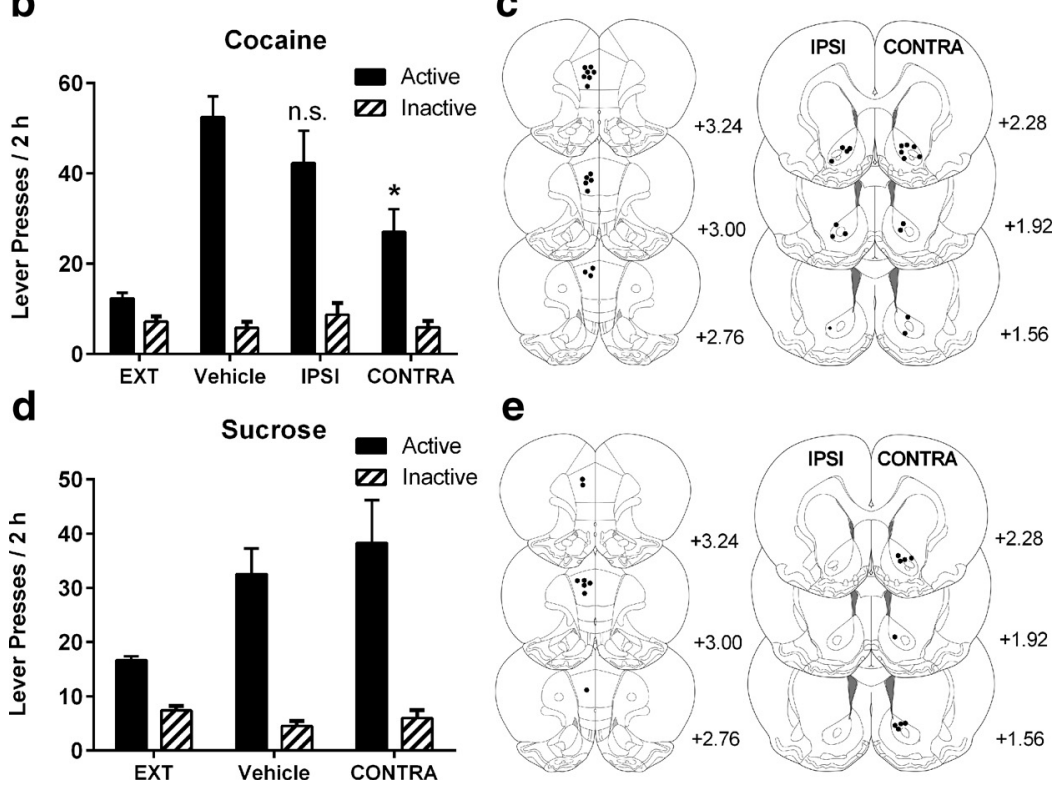

Figure 6. The PL to NACC pathway is recruited in a dopamine-dependent manner to drive cue-induced cocaine seeking. $\boldsymbol{a}$, Schematic of bilateral disconnection showing blockade of dopamine (DA) signaling in PL and glutamate signaling in either the ipsilateral or contralateral NACC immediately before reinstatement testing. $\boldsymbol{b}$, Microinfusions of the D1/D2 antagonist fluphenazine into PL plus the AMPA/NMDA antagonist mixture AP5/CNQX into contralateral (CONTRA) NAcC significantly attenuated reinstatement of active lever responding in response to cocaine cues relative to animals that received AP5/CNQX into ipsilateral (IPSI) NACC. Rats with ipsilateral AP5/CNQX microinjections into NACC showed similar reinstatement to rats that received microinfusions of aCSF in both sites. c, Placement of microinjectors in PL and NAcC of cocaine-trained rats included in reinstatement experiments. $\boldsymbol{d}$, Microinfusions of the same manner described in $\boldsymbol{b}$ had no effect on cued reinstatement of sucrose-seeking behavior. $\boldsymbol{e}$, Injection sites are displayed in PL and NAcC of sucrose-trained rats included for reinstatement experiments. Injection sites are displayed in a single hemisphere for clarity. Numbers indicate distance from bregma in the anteroposterior plane. Images adapted from the atlas of Paxinos and Watson (1998). ${ }^{*} p<0.05$. n.s., Not significant. Error

regions (e.g., vSub and BLA, or vSub and $\mathrm{mPFC}$ ) converge on the same neurons in NAc (French and Totterdell, 2002, 2003). These data indicate that a combination of multiple excitatory inputs may be involved in regulating NAc neural activity. Our results show that $\mathrm{PL}, \mathrm{BLA}$, and vSub neurons that activate during reinstatement of cocaine seeking all innervate NAcC. $\mathrm{NAcC}$ neurons that receive these multiple glutamate inputs may integrate corresponding, functionally distinct signals to mediate complex cognitive processes, including drug-seeking 

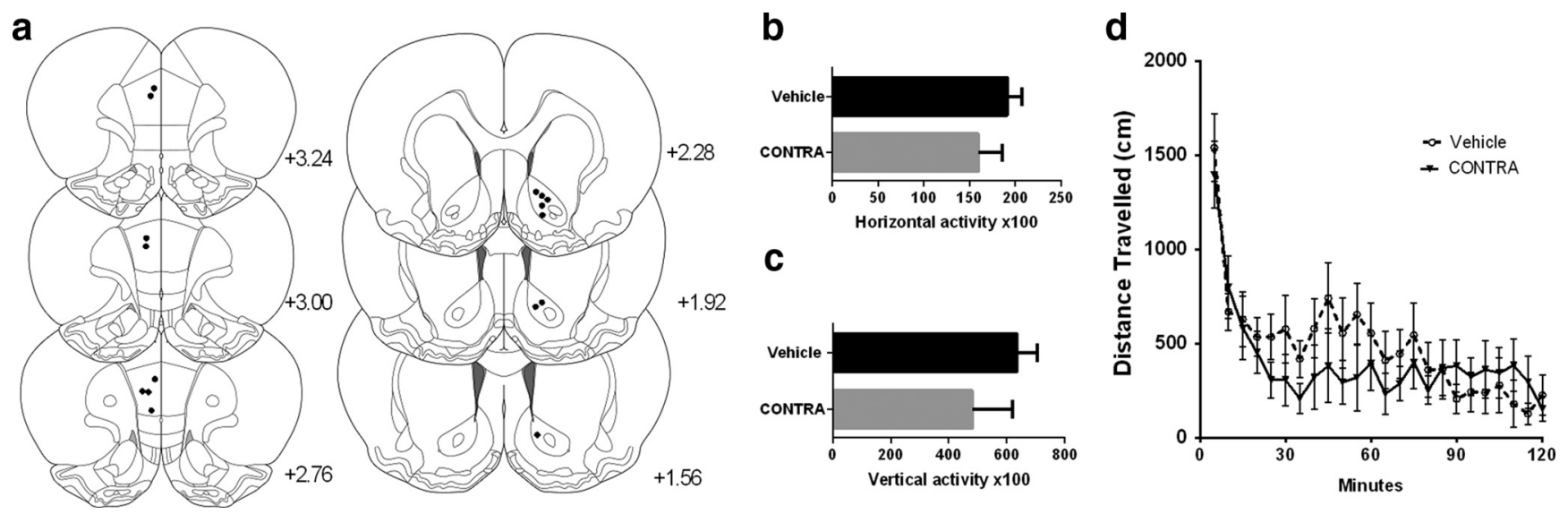

Figure 7. Blockade of the dopamine-PL-NAcC pathway was not associated with motor deficits. $\boldsymbol{a}$, Placement of microinjectors in PL and NAcC of rats tested for drug effects on locomotor activity. Injection sites are displayed in a single hemisphere for clarity. Microinjections of fluphenazine and AP5/CNQX in contralateral hemispheres had no effect on (b) horizontal or (c) vertical activity, nor did they affect $(\boldsymbol{d})$ total distance traveled over the $2 \mathrm{~h}$ test session ( $p$ values $>0.05$ ). Error bars indicate SEM.

behavior. The combined activation of these glutamatergic inputs to NAcC may make drug-associated cues more salient than sucrose-associated cues.

\section{Specific activation of PL projection to NAcC during cue- induced cocaine seeking, but not sucrose seeking} PL promotes drug seeking via its projection to NAcC (McFarland et al., 2003; Stefanik et al., 2013), but only subsets of neurons in PL are involved in drug-seeking behaviors (West et al., 2014; Moorman et al., 2015). Distinct cell populations characterized by their projection targets are gradually being disentangled (Taha and Fields, 2005; Bossert et al., 2011; Cruz et al., 2013, 2014). For example, different populations of mPFC neurons project to NAc versus VTA (Pinto and Sesack, 2000); and although cue-induced cocaine seeking activates PL neurons (Kufahl et al., 2009), this behavior does not activate PL projections to VTA (Mahler and Aston-Jones, 2012). Rather, we found that cue-induced reinstatement of cocaine seeking, but not sucrose seeking, activated the PL to NAcC circuit. This was similarly seen in BLA and vSub projections to NAcC. Importantly, however, the proportion of NAcCprojecting PL neurons that expressed Fos correlated with the intensity of cocaine seeking across rats, whereas similar correlations were not seen in BLA or vSub projections to NAcC during cocaine seeking or in PL projections to NAcC during sucrose seeking.

Notably, IL has also been implicated in drug abuse behaviors. IL inactivation, or inactivation of its projection to NAcSh, drives rats to reinstate extinguished cocaine seeking (Peters et al., 2008a, 2008b). However, inactivation of IL or its projection to NAcSh also attenuates drug seeking for heroin, cocaine, and methamphetamine (Koya et al., 2009; Rocha and Kalivas, 2010; Bossert et al., 2011, 2012). Because of these functional intricacies of the IL-NAcSh pathway, it is unsurprising that our results revealed similar Fos expression between extinction of cocaine selfadministration and cue-induced cocaine seeking in IL neurons that are retrogradely labeled from NAcSh.

\section{Disconnection of a dopamine-PL-NAcC pathway attenuates} cue-induced cocaine seeking, but not sucrose seeking

Given our anatomical evidence that cocaine cues preferentially recruit PL-NAcC projections, we explored the functional importance of this pathway using a pharmacological disconnection approach. This approach allowed us to confirm the necessity of glutamatergic projections from PL to NAcC in cued reinstatement behavior, as well to examine whether the activation of these projections relies on dopamine signaling. We showed that unilateral PL microinfusions of the D1/D2 antagonist fluphenazine, combined with microinfusions of the AMPA/NMDA receptor antagonist mixture AP5/CNQX into contralateral NAcC, were effective at attenuating cue-induced cocaine seeking, but not sucrose seeking, behavior. These findings indicate that PL glutamatergic neurons that project to $\mathrm{NAcC}$ are recruited by drug-related cues in a dopamine-dependent manner to drive drug-seeking behavior.

There is evidence for dopamine release from noradrenergic terminals in PFC (Devoto et al., 2001; Devoto and Flore, 2006). However, VTA is likely a major source of dopamine in PL, as PL receives dopaminergic input from fibers originating from the A10 group (Swanson, 1982), and VTA dopamine neurons are activated by food or drug-related Pavlovian cues (Yun et al., 2004; Corbit et al., 2007; Kufahl et al., 2009; Mahler et al., 2014). VTA DA terminals are most abundant in layer V of PL, where the majority of pyramidal cells projecting to the $\mathrm{NAcC}$ originate (Brog et al., 1993; Pinto and Sesack, 2000). Dendritic processes of NAcC-projecting PL neurons receive symmetric synaptic input from TH-immunopositive terminals (Carr et al., 1999), as do PL GABAergic interneurons (Sesack et al., 1995), indicating that dopamine may modulate the PL-NAcC pathway both directly and indirectly. Moreover, electrophysiological experiments have shown that NAcC-projecting PL cells are responsive to VTA stimulation or DA application (Jay et al., 1995; Yang and Seamans, 1996).

Our findings are consistent with behavioral studies that have tested the separate functional roles of dopamine signaling in $\mathrm{PL}$, or of PL inputs to NAcC, in drug seeking. For example, microinfusions of dopamine directly into PL reinstates cocaine-seeking behavior (Park et al., 2002), and intra-PL infusions of nonselective dopamine antagonists (fluphenazine or fluphenthixol), as well as D1- and D2-specific antagonists (SCH23390 or eticlopride, respectively), block reinstatement behavior elicited by a cocaine prime (McFarland and Kalivas, 2001) or heroinassociated cues (See, 2009). With respect to the PL-NAcC pathway, reinstatement of cocaine seeking is associated with increased glutamate levels in NAcC, which is blocked by inactivation of PL (McFarland et al., 2003), and optogenetic inhibition of PL inputs to NAcC prevents cocaine reinstatement behavior (Stefanik et al., 
2013, 2015). To our knowledge, ours is the first study to show that PL-NAcC glutamatergic projections are recruited by drugassociated cues and that activation of this pathway occurs in a dopamine-dependent manner. Importantly, this dopamine-PL$\mathrm{NAcC}$ circuit is not important for natural reward seeking behavior, indicating that this pathway may be uniquely involved in pathological reward seeking associated with addiction.

The bilateral disconnection approach is a powerful method to probe the function of the neural circuitry identified in anatomical studies, but it is important to highlight that this method is most effective in circuits with exclusively ipsilateral projections. Although the majority of pyramidal neurons in PL project to the ipsilateral NAcC, a number of these neurons project to the contralateral NAcC (Sesack et al., 1989). However, given that ipsilaterally treated rats exhibited reinstatement behavior that was indistinguishable from vehicle-treated controls, this contralateral PL-NAcC projection is unlikely to contribute significantly to cocaine-seeking behavior.

In conclusion, these results untangle important circuits in addiction pathology by identifying neuronal subpopulations activated during cue-conditioned cocaine seeking that target NAcC, but not NAcSh. We examined and compared multiple glutamatergic inputs to NAcC and NAcSh, and compared the proportions of neurons in these circuits that were Fos-activated during seeking for cocaine versus a natural reward (sucrose). We found that multiple, functionally distinct circuits activate and converge in NAcC during cue-induced reinstatement of cocaine seeking, but only neurons in the PL to NAcC circuit expressed Fos in a manner that correlated with active lever responding during cocaine seeking. The same circuits did not activate during cueinduced reinstatement of sucrose seeking. Consistent with these anatomical results, pharmacological disconnection of the PLNAcC pathway prevented reinstatement of seeking of cocaine seeking, but not sucrose seeking, and also showed an important role for dopamine in engaging the requisite PL-NAcC pathway for this drug-seeking behavior. As such, subpopulations of PL neurons that project to NAcC, and their regulation by dopamine, are potential therapeutic targets for treating cocaine relapse.

\section{References}

Bäckström P, Hyytiä P (2007) Involvement of AMPA/kainate, NMDA, and mGlu5 receptors in the nucleus accumbens core in cue-induced reinstatement of cocaine seeking in rats. Psychopharmacology 192:571-580. CrossRef Medline

Bossert JM, Poles GC, Wihbey KA, Koya E, Shaham Y (2007) Differential effects of blockade of dopamine D1-family receptors in nucleus accumbens core or shell on reinstatement of heroin seeking induced by contextual and discrete cues. J Neurosci 27:12655-12663. CrossRef Medline

Bossert JM, Stern AL, Theberge FR, Cifani C, Koya E, Hope BT, Shaham Y (2011) Ventral medial prefrontal cortex neuronal ensembles mediate context-induced relapse to heroin. Nat Neurosci 14:420-422. CrossRef Medline

Bossert JM, Stern AL, Theberge FR, Marchant NJ, Wang HL, Morales M, Shaham Y (2012) Role of projections from ventral medial prefrontal cortex to nucleus accumbens shell in context-induced reinstatement of heroin seeking. J Neurosci 32:4982-4991. CrossRef Medline

Britt JP, Benaliouad F, McDevitt RA, Stuber GD, Wise RA, Bonci A (2012) Synaptic and behavioral profile of multiple glutamatergic inputs to the nucleus accumbens. Neuron 76:790-803. CrossRef Medline

Brog JS, Salyapongse A, Deutch AY, Zahm DS (1993) The patterns of afferent innervation of the core and shell in the "accumbens" part of the rat ventral striatum: immunohistochemical detection of retrogradely transported fluoro-gold. J Comp Neurol 338:255-278. CrossRef Medline

Calhoon GG, O'Donnell P (2013) Closing the gate in the limbic striatum: prefrontal suppression of hippocampal and thalamic inputs. Neuron 78: 181-190. CrossRef Medline
Carr DB, O'Donnell P, Card JP, Sesack SR (1999) Dopamine terminals in the rat prefrontal cortex synapse on pyramidal cells that project to the nucleus accumbens. J Neurosci 19:11049-11060. Medline

Cason AM, Aston-Jones G (2013) Role of orexin/hypocretin in conditioned sucrose-seeking in rats. Psychopharmacology 226:155-165. CrossRef Medline

Chaudhri N, Sahuque LL, Schairer WW, Janak PH (2010) Separable roles of the nucleus accumbens core and shell in context- and cue-induced alcohol-seeking. Neuropsychopharmacology 35:783-791. CrossRef Medline

Corbit LH, Janak PH, Balleine BW (2007) General and outcome-specific forms of Pavlovian-instrumental transfer: the effect of shifts in motivational state and inactivation of the ventral tegmental area. Eur J Neurosci 26:3141-3149. CrossRef Medline

Cruz FC, Koya E, Guez-Barber DH, Bossert JM, Lupica CR, Shaham Y, Hope BT (2013) New technologies for examining the role of neuronal ensembles in drug addiction and fear. Nat Rev Neurosci 14:743-754. CrossRef Medline

Cruz FC, Babin KR, Leao RM, Goldart EM, Bossert JM, Shaham Y, Hope BT (2014) Role of nucleus accumbens shell neuronal ensembles in contextinduced reinstatement of cocaine seeking. J Neurosci 34:7437-7446. CrossRef Medline

Devoto P, Flore G (2006) On the origin of cortical dopamine: is it a cotransmitter in noradrenergic neurons? Curr Neuropharmacol 4:115-125. CrossRef Medline

Devoto P, Flore G, Pani L, Gessa GL (2001) Evidence for co-release of noradrenaline and dopamine from noradrenergic neurons in the cerebral cortex. Mol Psychiatry 6:657-664. CrossRef Medline

Di Ciano P, Everitt BJ (2004) Direct interactions between the basolateral amygdala and nucleus accumbens core underlie cocaine-seeking behavior by rats. J Neurosci 24:7167-7173. CrossRef Medline

Everitt BJ, Parkinson JA, Olmstead MC, Arroyo M, Robledo P, Robbins TW (1999) Associative processes in addiction and reward: the role of amygdala-ventral striatal subsystems. Ann N Y Acad Sci 877:412-438. CrossRef Medline

Floresco SB (2015) The nucleus accumbens: an interface between cognition, emotion, and action. Annu Rev Psychol 66:25-52. CrossRef Medline

French SJ, Totterdell S (2002) Hippocampal and prefrontal cortical inputs monosynaptically converge with individual projection neurons of the nucleus accumbens. J Comp Neurol 446:151-165. CrossRef Medline

French SJ, Totterdell S (2003) Individual nucleus accumbens-projection neurons receive both basolateral amygdala and ventral subicular afferents in rats. Neuroscience 119:19-31. CrossRef Medline

Fuchs RA, Evans KA, Parker MC, See RE (2004) Differential involvement of the core and shell subregions of the nucleus accumbens in conditioned cue-induced reinstatement of cocaine seeking in rats. Psychopharmacology 176:459-465. CrossRef Medline

Groenewegen HJ, Vermeulen-Van der Zee E, te Kortschot A, Witter MP (1987) Organization of the projections from the subiculum to the ventral striatum in the rat: a study using anterograde transport of Phaseolus vulgaris leucoagglutinin. Neuroscience 23:103-120. CrossRef Medline

Groenewegen HJ, Wright CI, Beijer AV, Voorn P (1999) Convergence and segregation of ventral striatal inputs and outputs. Ann N Y Acad Sci 877: 49-63. CrossRef Medline

Hollander JA, Carelli RM (2007) Cocaine-associated stimuli increase cocaine seeking and activate accumbens core neurons after abstinence. J Neurosci 27:3535-3539. CrossRef Medline

Ito R, Robbins TW, Everitt BJ (2004) Differential control over cocaineseeking behavior by nucleus accumbens core and shell. Nat Neurosci 7:389-397. CrossRef Medline

Jay TM, Glowinski J, Thierry AM (1995) Inhibition of hippocampoprefrontal cortex excitatory responses by the mesocortical DA system. Neuroreport 6:1845-1848. CrossRef Medline

Kalivas PW (2009) The glutamate homeostasis hypothesis of addiction. Nat Rev Neurosci 10:561-572. CrossRef Medline

Kalivas PW, Volkow ND (2005) The neural basis of addiction: a pathology of motivation and choice. Am J Psychiatry 162:1403-1413. CrossRef Medline

Koya E, Uejima JL, Wihbey KA, Bossert JM, Hope BT, Shaham Y (2009) Role of ventral medial prefrontal cortex in incubation of cocaine craving. Neuropharmacology 56 [Suppl 1]:177-185.

Kufahl PR, Zavala AR, Singh A, Thiel KJ, Dickey ED, Joyce JN, Neisewander 
JL (2009) c-Fos expression associated with reinstatement of cocaineseeking behavior by response-contingent conditioned cues. Synapse 63: 823-835. CrossRef Medline

Mahler SV, Aston-Jones GS (2012) Fos activation of selective afferents to ventral tegmental area during cue-induced reinstatement of cocaine seeking in rats. J Neurosci 32:13309-13326. CrossRef Medline

Mahler SV, Vazey EM, Beckley JT, Keistler CR, McGlinchey EM, Kaufling J, Wilson SP, Deisseroth K, Woodward JJ, Aston-Jones G (2014) Designer receptors show role for ventral pallidum input to ventral tegmental area in cocaine seeking. Nat Neurosci 17:577-585. CrossRef Medline

Martín-García E, Courtin J, Renault P, Fiancette JF, Wurtz H, Simonnet A, Levet F, Herry C, Deroche-Gamonet V (2014) Frequency of cocaine self-administration influences drug seeking in the rat: optogenetic evidence for a role of the prelimbic cortex. Neuropsychopharmacology 39: 2317-2330. CrossRef Medline

McFarland K, Kalivas PW (2001) The circuitry mediating cocaine-induced reinstatement of drug-seeking behavior. J Neurosci 21:8655-8663. Medline

McFarland K, Lapish CC, Kalivas PW (2003) Prefrontal glutamate release into the core of the nucleus accumbens mediates cocaine-induced reinstatement of drug-seeking behavior. J Neurosci 23:3531-3537. Medline

McGinty VB, Grace AA (2009) Timing-dependent regulation of evoked spiking in nucleus accumbens neurons by integration of limbic and prefrontal cortical inputs. J Neurophysiol 101:1823-1835. CrossRef Medline

McLaughlin J, See RE (2003) Selective inactivation of the dorsomedial prefrontal cortex and the basolateral amygdala attenuates conditioned-cued reinstatement of extinguished cocaine-seeking behavior in rats. Psychopharmacology 168:57-65. CrossRef Medline

Mogenson GJ, Jones DL, Yim CY (1980) From motivation to action: functional interface between the limbic system and the motor system. Prog Neurobiol 14:69-97. CrossRef Medline

Moorman DE, Aston-Jones G (2015) Prefrontal neurons encode contextbased response execution and inhibition in reward seeking and extinction. Proc Natl Acad Sci U S A 112:9472-9477. CrossRef Medline

Moorman DE, James MH, McGlinchey EM, Aston-Jones G (2015) Differential roles of medial prefrontal subregions in the regulation of drug seeking. Brain Res 1628:130-146. CrossRef Medline

Mulder AB, Hodenpijl MG, Lopes da Silva FH (1998) Electrophysiology of the hippocampal and amygdaloid projections to the nucleus accumbens of the rat: convergence, segregation, and interaction of inputs. J Neurosci 18:5095-5102. Medline

Müller R, Bravo R, Burckhardt J, Curran T (1984) Induction of c-fos gene and protein by growth factors precedes activation of c-myc. Nature 312: 716-720. CrossRef Medline

National Research Council (2011) Guide for the care and use of laboratory animals, Ed 8. Washington, DC: National Academies.

O’Donnell P, Grace AA (1995) Synaptic interactions among excitatory afferents to nucleus accumbens neurons: hippocampal gating of prefrontal cortical input. J Neurosci 15:3622-3639. Medline

Park WK, Bari AA, Jey AR, Anderson SM, Spealman RD, Rowlett JK, Pierce RC (2002) Cocaine administered into the medial prefrontal cortex reinstates cocaine-seeking behavior by increasing AMPA receptor-mediated glutamate transmission in the nucleus accumbens. J Neurosci 22:29162925. Medline

Parkinson JA, Olmstead MC, Burns LH, Robbins TW, Everitt BJ (1999) Dissociation in effects of lesions of the nucleus accumbens core and shell on appetitive Pavlovian approach behavior and the potentiation of conditioned reinforcement and locomotor activity by $\mathrm{D}$-amphetamine. J Neurosci 19:2401-2411. Medline

Paxinos G, Watson C (1998) The rat brain in stereotaxic coordinates, Ed 4. San Diego: Academic.

Paxinos G, Watson C (2007) The rat brain in stereotaxic coordinates, Ed 6. San Diego: Academic.

Pennartz CM, Groenewegen HJ, Lopes da Silva FH (1994) The nucleus accumbens as a complex of functionally distinct neuronal ensembles: an integration of behavioural, electrophysiological and anatomical data. Prog Neurobiol 42:719-761. CrossRef Medline

Peters J, LaLumiere RT, Kalivas PW (2008a) Infralimbic prefrontal cortex is responsible for inhibiting cocaine seeking in extinguished rats. J Neurosci 28:6046-6053. CrossRef Medline

Peters J, Vallone J, Laurendi K, Kalivas PW (2008b) Opposing roles for the ventral prefrontal cortex and the basolateral amygdala on the spontaneous recovery of cocaine seeking in rats. Psychopharmacology 197: 319-326. CrossRef Medline

Pinto A, Sesack SR (2000) Limited collateralization of neurons in the rat prefrontal cortex that project to the nucleus accumbens. Neuroscience 97:635-642. CrossRef Medline

Rocha A, Kalivas PW (2010) Role of the prefrontal cortex and nucleus accumbens in reinstating methamphetamine seeking. Eur J Neurosci 31: 903-909. CrossRef Medline

Sartor GC, Aston-Jones GS (2012) A septal-hypothalamic pathway drives orexin neurons, which is necessary for conditioned cocaine preference. J Neurosci 32:4623-4631. CrossRef Medline

See RE (2009) Dopamine D1 receptor antagonism in the prelimbic cortex blocks the reinstatement of heroin-seeking in an animal model of relapse. Int J Neuropsychopharmacol 12:431-436. CrossRef Medline

Sesack SR, Deutch AY, Roth RH, Bunney BS (1989) Topographical organization of the efferent projections of the medial prefrontal cortex in the rat: an anterograde tract-tracing study with Phaseolus vulgaris leucoagglutinin. J Comp Neurol 290:213-242. CrossRef Medline

Sesack SR, Snyder CL, Lewis DA (1995) Axon terminals immunolabeled for dopamine or tyrosine hydroxylase synapse on GABA-immunoreactive dendrites in rat and monkey cortex. J Comp Neurol 363:264-280. CrossRef Medline

Smith RJ, See RE, Aston-Jones G (2009) Orexin/hypocretin signaling at the orexin 1 receptor regulates cue-elicited cocaine seeking. Eur J Neurosci 30:493-503. CrossRef Medline

Stefanik MT, Kalivas PW (2013) Optogenetic dissection of basolateral amygdala projections during cue-induced reinstatement of cocaine seeking. Front Behav Neurosci 7:213. CrossRef Medline

Stefanik MT, Moussawi K, Kupchik YM, Smith KC, Miller RL, Huff ML, Deisseroth K, Kalivas PW, LaLumiere RT (2013) Optogeneticinhibition of cocaine seeking in rats. Addict Biol 18:50-53. CrossRef Medline

Stefanik MT, Kupchik YM, Kalivas PW (2016) Optogenetic inhibition of cortical afferents in the nucleus accumbens simultaneously prevents cueinduced transient synaptic potentiation and cocaine-seeking behavior. Brain Struct Funct 221:1681-1689. CrossRef Medline

Stern EA, Jaeger D, Wilson CJ (1998) Membrane potential synchrony of simultaneously recorded striatal spiny neurons in vivo. Nature 394:475478. CrossRef Medline

Sun W, Rebec GV (2003) Lidocaine inactivation of ventral subiculum attenuates cocaine-seeking behavior in rats. J Neurosci 23:10258-10264. Medline

Swanson LW (1982) The projections of the ventral tegmental area and adjacent regions: a combined fluorescent retrograde tracer and immunofluorescence study in the rat. Brain Res Bull 9:321-353. CrossRef Medline

Taha SA, Fields HL (2005) Encoding of palatability and appetitive behaviors by distinct neuronal populations in the nucleus accumbens. J Neurosci 25:1193-1202. CrossRef Medline

Vertes RP (2004) Differential projections of the infralimbic and prelimbic cortex in the rat. Synapse 51:32-58. CrossRef Medline

West EA, Saddoris MP, Kerfoot EC, Carelli RM (2014) Prelimbic and infralimbic cortical regions differentially encode cocaine-associated stimuli and cocaine seeking before and following abstinence. Eur J Neurosci 39: 1891-1902. CrossRef Medline

Yang CR, Seamans JK (1996) Dopamine D1 receptor actions in layers V-VI rat prefrontal cortex neurons in vitro: modulation of dendritic-somatic signal integration. J Neurosci 16:1922-1935. Medline

Young ST, Porrino LJ, Iadarola MJ (1991) Cocaine induces striatal c-fosimmunoreactive proteins via dopaminergic D1 receptors. Proc Natl Acad Sci U S A 88:1291-1295. CrossRef Medline

Yun IA, Wakabayashi KT, Fields HL, Nicola SM (2004) The ventral tegmental area is required for the behavioral and nucleus accumbens neuronal firing responses to incentive cues. J Neurosci 24:2923-2933. CrossRef Medline

Zhou L, Pruitt C, Shin CB, Garcia AD, Zavala AR, See RE (2014) Fos expression induced by cocaine-conditioned cues in male and female rats. Brain Struct Funct 219:1831-1840. CrossRef Medline 